\title{
Representations in Intergroup Relations: Reflexivity, Meta-Representations, and Interobjectivity
}

\author{
Wolfgang Wagner ${ }^{\circledR}$, Maaris Raudsepp ${ }^{2}$ \\ ${ }^{1}$ University of Tartu, \\ 2 Näituse, Tartu, 50409, Republic of Estonia \\ ${ }^{2}$ Tallinn University, \\ 5 Uus-Sadama, Tallinn, 10120, Republic of Estonia \\ wolfgang.wagner@ut.ee
}

\begin{abstract}
Social and cultural groups are characterised by shared systems of social objects and issues that constitute their objective reality and their members' identity. It is argued that interpersonal interactions within such groups require a system of comprehensive representations to enable concerted interaction between individuals. Comprehensive representations include bits and pieces of the interactant's representational constitution and potential values and behaviours to reduce possible friction in interactions. On a larger scale, the same is true in encounters, communication, and interaction between members of different cultural groups where interactants need to dispose of a rough knowledge of the other culture's relevant characteristics. This mutual knowledge is called meta-representations that complement the actors' own values and ways of thinking. This concept complements Social Representation Theory when applied to cross-cultural and inter-ethnic interactions.
\end{abstract}

Key words: social representation theory, intergroup behaviour, cooperation, metarepresentation, interobjectivity, comprehensive representations

\section{Universes of discourse}

It is easy to see that two persons speaking different languages and being from different cultures will not understand each other. Not even speaking the same language will guarantee that two individuals will be able to converse. If, for example, one asked "Can you tell me whether you are the fifth reincarnation of the holy dog or not?" in English language and the partner understood English, but not the meaning of 'being the reincarnation of a holy dog', the only rationally available response to this question would be "I am sorry, but I don't understand". In other words the conversation partner would need to reject the question in its entirety instead of saying 'yes I am' or 'no I'm not'. By rejecting the question as a whole, the conversation partner refers to the content of the question, that violates the necessary agreement in any communication to establish a shared space of

(C) Wagner W., Raudsepp M., 2021

(c) () This work is licensed under a Creative Commons Attribution 4.0 International License https://creativecommons.org/licenses/by/4.0/ 
representations. In the present example it would mean to agree on what a number of reincarnations means, what a holy dog is, and what these have to do with persons (Wagner, Hayes, 2005).

Something to that effect may a German secondary school teacher have had in mind, when she discussed the case of Samuel Paty who was murdered by a Muslim student after having staged a discussion about caricatures of the prophet Mohammad in class. After the discussion of the Paty murder case a ninth-grade girl started to weep. When asked why she wept, the teacher may have been left incredulous, because the pupil did neither weep for the victim, nor for the murderer, who had been shot by police while fleeing, but for the offended prophet (MENA Research and Studies Center, 2021). This example illustrates a cultural divide that was not easily bridged despite the shared language of teacher and pupil. Hence, discursive understanding presupposes a shared system of representations and attached feelings. This prerequisite of any communication is a truism and sometimes addressed by the simplified concept of 'grounding' (Clark, Brennan, 1991).

In the present text we will discuss the processes that unfold when members of different groups or cultures attempt to bootstrap communication across their differences, that is processes that go beyond sharing a language.

\section{Reflexive groups: it takes at least two to tango}

It is clear that groups do not live in isolation and in fact, it would be nearly impossible to imagine an aggregate of people living in a completely isolated place. Groups usually have neighbours with whom they cultivate economic and social relations even in places that are as far from each other as Pacific islands. Such social groups are characterized by their specific group identity, their representational system defining their symbolic world, customary behaviours, and social objects. The concept of a 'social group', hence, is co-extensive with an aggregate of people who are aware that there are people outside and beyond their own group's confines and who maintain a system of identity, social objects, and a symbolic world that is different or even opposite to their own. The awareness of others being different to a certain degree from one's own compatriots justifies, indeed necessitates constructing and accentuating an ingroup identity that marks the aggregate of people as a unity. In other words, these people form a reflexive group.

An aggregate of people who identify each other as belonging together and who engage in attempts to differ from others falls squarely under the epistemological term 'group'. Hence, conceptually a bunch of people to be called a group presupposes a neighbouring bunch of people, who contrast with certain elements of their local customs and representational system: Groups only exist in multiples. As a corollary, the whole of humankind on earth does not constitute a group by themselves. Humankind could conceptually only be called a group if humans were confronting some extraterrestrials or interacting with non-human species.

The truism of at least two groups constituting each other is often disregarded in social psychology. A consequence of omitting this precondition is that social representations are not recognized as being intimately linked to social identities. Hence, talking about the identity of one group needs mention of the counterpart group from which it differentiates itself (Tajfel, 1978). 'Reflexive group', 
hence, refers to the collective whose individual members' identities are the result of self-categorization (Turner, Reynolds, 2012). If people categorize themselves and others as being part of a specific social unit, this unit constitutes a reflexive group. That is, a group results from the identity processes of its members and its reflexive character denotes the fact that members can point out to which collective they feel belonging emotionally and cognitively (Breakwell, 2015). Reflexive groups are characterized by regular social discourse that enables them to create, maintain and change their shared social reality, that is the representations, practices, and social objects. Nominal and therefore non-reflexive groups do not have this capacity (Wagner, Hayes, 2005).

Groups do not only differ from each other by their name and attached affect and meaning but also by the way they elaborate the social objects that populate their social world. This concerns the way they interact with compatriotes and objects and by the way they represent these objects, which is a social achievement (Moscovici, 2000; Wagner et al., 2018; Jovchelovitch, 2019). The theory of social representations is interested in understanding how conversations, mass media, and contemporary internet media make the members of groups converge in understanding a novel and sometimes threatening object or issue (cf. Moliner, Bovina, 2020). This collective activity resembles a process of symbolic coping with a novelty that threatens the customary way of life (Ben-Asher et al., 2006; Wagner et al., 2002). Naturally, just as individuals think, chat about, and form an impression of their neighbours, groups also converse and deliberate over other groups that figure in their local universe. In doing so, they will develop a social representation of the other group's appearance and of what they believe that the other group's members believe.

We argue that any theoretical approach or research dealing with aspects of how one group perceives, stereotypes, and treats another group in a friendly or unfriendly way, needs to be complemented by theorizing and researching the counterpart group's reverse perceptions, stereotyping, and treatment of the first group. A research perspective on relations between groups is utterly incomplete if it does not encompass both poles of the intergroup relationship, that is at least the two reflexive groups confronting each other (Sen \& Wagner, 2005; Putra, Wagner, 2017). Besides the dialogical approach in social representation theory (Marková, 2016) this necessity of mutual foundations in intergroup relations has been frequently neglected in the past and resulted in often biased and lopsided research. Taking the intergroup perspective seriously implies a discussion of social identities and the group members' awareness of the limits of their representations' space of validity.

\section{Concerted interaction and the public}

As shown in the introductory remarks, group members identify in relation to other groups and develop their specific local world and its social objects that may be more or less different from those of others. The difference from others circumscribes the space of where a person's social representations, that is their understanding of social objects is valid and where co-members of the group will be able to engage in effortless communication. That is, notwithstanding the fact that many human affairs take place in private, the understanding of what commonly tran- 
spires between people in private spheres is potentially accessible to most others; that is, the potential for understanding is part of the public common-sense even though the details of a specific private affair between particular persons are not. Privacy, hence, is not the opposite of the public because both converge in the symbolic representations that define a group's world. This is also illustrated by the fact that persons can effortlessly converse about public and private issues, be that dreams, troubles in personal relationships, or other issues. This is nicely illustrated in the smooth workings of interactions in the public space (Jovchelovitch, 2001). As a consequence, social objects, issues, and institutions are the objectified instances of a group's system of social representations and one can say that in smooth interactions the intersubjective is coextensive with the objective world of a group.

Clearly societies and groups are not homogeneous aggregates of people, but characterized by hierarchies and divisions that depend on the specific activities individuals are engaged in. Consequently, not all members of a reflexive group do, or need to dispose of the same set of representational knowledge. There is only a subset of socially relevant representations that are required to allow common interactions between people pertaining to any of the many different factions and classes of a group or society. For enabling such concerted interactions the interactants need the repertoir of general social representations and related courses of action that shape the behavioural fabric of public encounters, but also a rough impression of the behavioural and representational elements of others who belong to different societal sub-groups and factions together with their attached repertoir of background knowledge (Wagner, 1995). Conversations, for example, will only be successful, if each speaker takes account of their counterparts' 'alternative' ideas (Gillespie, 2008).

Encounters may require symmetric or complementary actions by the interactants and each of them must have at their disposal a rough impression of the interaction-relevant elements of the other's actions. These are comprehensive representations of one's own and another person's interaction space. Such groupspecific representations have been called 'holomorphic' to characterise their comprehensive character embracing own and others' representations (Wagner, 1995. P. 128). It must be noted that such comprehensive representations are formed in a public discourse where everybody is free to participate either as actor or incidentally. If individuals are prevented from participation, for example as the result of imprisonment or other condition, it means a significant burden for their reintegration into the group.

The importance of comprehensive representations is shown by research about professional and organizational socialization. Vocational training only partly consists of imparting functional skills. An equally large part of the training effort consists of teaching comprehensive representations and behaviours, informal codes, jargon, role status, and the unwritten standards of performance. These processes take place at all levels of an organization and convey to new members of an institution not only their professional representations and habits, but also those of their potential interaction partners. The result of such trainings is expected to be a high level of cultural competence (e.g. Levine, Moreland, 1991; Page, 2005; Cornelissen, Van Wyk, 2008; Berry et al., 2010). 


\section{Intergroup meta-representations and interobjectivity}

\section{Knowing something about the other: meta-representations}

Cultural groups may live relatively far from each other, if they, for example inhabit separate regions, which do not promote everyday contact. Conversely, such groups may also live in close vicinity, as is the case with ethnic groups living as a minority in a larger ethnically different majority. This is the frequent situation in Western countries where people from different cultures, for example in the wake of colonialism or during more recent migratory movements, settle within European countries. In this case minorities and majority populations are separated by physical as well as symbolic boundaries. They are physical when it comes to the buildings, practices and behaviours a group maintains to shape its environment and they are symbolic with regard to the representational system spanning the beliefs, values and norms that structure the discourse among members. In other words, the set of objects and issues that define a group exist side by side with the set of objects and issues that define other groups. In this situation the groups in contact are hard pressed to find an arrangement that deflects conflict-prone conditions, that allows mutual co-existence, and that furthers collaborative exchange across groups and across their objectified representational systems.

The situation of establishing a more or less frictionless collaboration requires a certain amount of mutual understanding. That is a kind of knowledge that allows to anticipate the likely actions of the culturally distinct member and what to expect from the other in such everyday situations. Hence we are looking at a situation where interaction requires to construct a cooperational meaning that comprises a person's own action-relevant rules, as well as the rules underlying the actions of potential co-actors. This is what we call a meta-representation (Raudsepp, 2005; Wagner, Hayes, 2005; Wagner, 2021).

Meta-representations allow flexible responses to action moves of an interactant that is not intimately known as is often the case in cross-cultural encounters. Interactants need to reconstruct the socially relevant objects, issues and institutions that relate to the situation. They orient both actors' social behaviour towards each other so that concerted co-operation preserves and reproduces the social conditions. If meaningful interchange and practice is to be established ideally both interactants would maintain mutual meta-representations that reflect the essential aspects of the entire situation including the respective groups. Without mutual meta-representations the actors cannot meaningfully enact the encounter. Representations and meta-representation are a functional necessity for members of groups in contact; they are a prerequisite of meaningful interaction.

More often than not groups in contact will take different positions on the ladder of status. When there are majority and minority populations where the latter often take a subordinate and less powerful position than the former. For even, but particularly for encounters of group members with unequal status metarepresentations are crucial. Interactions will involve either similar or complementary behaviours depending on whether the interactants are facing each other as equals or act from different hierarchical positions. For example, interaction within a hierarchy conditions involves complementary behaviour patterns with the superior and with the subordinate actor. Although different, the patterns of action of those 
involved in the hierarchy complement each other in such a way that they create, or rather confirm, the social reality of dominance.

Moscovici (1988. P. 221) distinguishes between hegemonic, emancipated and polemical representations where hegemonic representations are those that prevail in large parts of a 'thinking society' and that are undisputed and emancipated representations exist side by side being shared among groups. Polemical representations belong to different factions in conflict and are brought to bear in disputes. Now, even polemical representations arising in conflict and not being shared among the antagonistic parties need to embrace knowledge from the others worldview to some degree. The respective meta-representations in a polemic setting are required for debate and argument in antagonistic discourse. Metarepresentations allow to anticipate what can be said and to which effect it can be said in conflict situations. If parties in conflict did not share a certain degree of mutual knowledge, even dispute would not work.

The importance of meta-representations that members of one cultural group construct about another ethnic group is highlighted in the preconditions of violent conflict. For politicians with an interest in stoking conflict between cultural groups it is crucial to gain influence on what members of one group think about the members of the other group. In other words, intergroup conflict crucially depends on the meta-representations that members of a reflexive group construct about an opposite group. In most of the cases where ethnic groups live side by side encounters of members of different groups in everyday life are rarely conflictual in an ethnic sense. Such encounters are governed by rational considerations from both sides, be it in a situation of conversation, gossip, and small talk, in a situation of commercial exchange in shopping, or collaboration at a workplace.

The situation changes once overarching political interests are at stake. In India, the relationship between Hindus and minority Muslims usually does not play a role in the walks of everyday life. People follow their daily chores that may lead them to regularly interact with members of the other ethnic group. However, as it happened repeatedly during the last seventy years, a rising ethno-nationalism stoked by politicians from, e.g. the Hindutva side, lead people to reconstruct their image and meta-representation of the outgroup not as fellow humans but as adversaries in a struggle for symbolic power and religious dominance (Sen \& Wagner, 2005; Sen \& Wagner, 2009).

Similar processes are at work in interreligious conflict in Indonesia, where Sunni-Muslims can develop toxic meta-representations about Ahmadina-Muslims that may erupt in violence (Putra, Wagner, 2017) and Gagnon's (2004) study of the Yugoslav war in the nineteen-nineties is a particularly clear example of an elite's political interests in shaping inter-ethnic meta-representations. During most of the time that Yugoslavia existed as a multi-ethnic country, inter-ethnic relations were friendly and supportive. This is illustrated by the high number of inter-ethnic marriages before the war that started in 1991. In 2006, however, a survey showed a significant decline of willingness to marry members of an opposing ethnic group in most of the new states that emerged (Elcheroth, Reicher, 2017. P. 185). Driven by power interests of the dominant Serb elite, who needed to shake the mostly peaceful - with the exception of Kosovo - mixed existence of 
ethnic groups in order to secure their power within the Serbian political ranks. Their way of planting distrust between groups was to create the impression of others as a source of danger and enmity, partly by staged violence. Which family father could remain relaxed once the neighbours with their marked ethnic difference became represented as potential aggressors (Gagnon, 2004)? Another example of such a top-down escalation of conflict by promoting negative mutual metarepresentations and incompatible views on the WWII was the so called Bronze soldier event in Tallinn (Raudsepp, Wagner, 2012).

However, toxic meta-representations can sometimes be defused. Media campaigns have been successful in post-conflict countries in changing perceived social norms (Paluck, Green, 2009a, 2009b). Extensive media campaigns which were designed as social experiments in Rwanda (Paluck, 2009) and Burundi (Bilali, 2014; Bilali \& Staub, 2017) were targeted at the whole population, aiming at healing post-conflict trauma and improving intergroup relations. In Rwanda a radio soap opera script was written in collaboration with local experts and psychologists and tested on different target groups. Then a weekly radio serial depicted the development of conflict between two fictional communities, with vivid outcomes of the conflict and paths of reconciliation. By showing various widespread representations, the program aimed to change beliefs using didactic messages and to influence perceived norms and metarepresentations through realistic radio characters who could speak to audience experiences and function as positive role models.

\section{Establishing commonality: interobjectivity}

Social Representation Theory belongs to the class of theories of social construction. Social representations are constructed in the communications, conversations, and discourses occurring in groups, be it on a personal basis, through mass media, or via electronic and social media. The result of such discursive constructions is an organised set of social objects that defines the living world of a group and its members. The objects populating this local world are characterised by shared meaning and attached symbolism and they are also represented by the ways how group members communicate about the social object and how they behave and interact with regard to the object (Wagner, 2015). In the case of imaginary issues such as deities and other abstract ideas, it is the interaction of group members that 'materially' enacts the object as a particular pattern of interrelationships. Social objects can be holy places of worship, a wheelchair for a handicapped person, the new facts of global warming being the issue in debates and media reporting, and even large scale social identities that define and delimit the boundaries of ethnic and other groups (Wagner et al., 2018).

Given the constitutive character of such a system of social objects for the identity and emotional stability of groups, such systems can rightly be regarded the objective reality of the respective group. Intergroup situations, hence, can be understood as encounters of two different objectivities, particularly if we consider ethnic groups and cultures that are prime examples of divergent realities. The task in intergroup encounters then is to establish a communicative bridge of mutual understanding between the two objectivities that exceeds mere language barriers. If the communicative bridging by the help of meta-representations and 
open communication is successful, one can say that the shared understanding constitutes an interobjective space between the respective groups (Moghaddam, 2003; Harré \& Sammut, 2013).

A theoretical analysis of these processes shows that the success of establishing a true interobjective space that allows fruitful interaction and collaboration is not guaranteed if the value systems of the groups grossly contradict each other. Establishing interobjectivity requires an openness, a positive and accepting attitude of the opposing group's value system. Contradictive values and norms pose an ethical obstacle that one or both interactants may not be able to cross. Imagine a European who upholds the historical values of the enlightenment and of human rights, who meets a proponent of a slave holder society (e.g. Global Slavery Index, 2018). Accepting the slave holder values of the unequal value of human beings would utterly collide with the European's understanding of human equality and in fact constitute an identity threat. A similar contradiction applies to the slave holder person who may be incredulous of ascribing black people the same moral value as white people (Wagner, 2021).

There are many processes that unfold when members of different groups or cultures attempt to bootstrap communication across their differences. Bridging the representational gap between divergent subjects is possible by using two kinds of resources: metarepresentations, that is obtaining an impression of the other's identity and representational system as described above, and suitable communicative arrangements such as ritualized interaction, a phatic communication style, and fitting non-verbal signals (Padilla Cruz, 2010; Krys et al., 2016). Mutual metarepresentations of others' beliefs are necessary to regulate the content of contact either avoiding sensitive issues or negotiating an inter-objective space that is accessible to both partners. Consequently, the logical chain of interaction between representatives of divergent objectivities consists of: 1) meta-representations that are basis for mutual expectations, 2) ritualized communication and phatic communications for initiating and preserving bootstrapping the contact, 3) co-constructing a joint inter-objective field (Wagner, 2021).

Besides logical and conceptual incompatibilities between representational systems, a successful interaction may be hindered by affective reasons when threat to one's identity is felt due to perceived incommensurability of values or moral axioms. Sometimes apparent incommensurabilities may be overcome by certain strategies leading to successful bootstrapping and benevolent contact, and vice versa irrespective of the compatibility of representational systems, it is of course possible to turn intergroup relations into hostility. That is, if interactants do not intend to establish interobjectivity, any minimal difference in representations can serve to rationalise conflict, and highlight ethical or affective incommensurability.

Tentatively we can enumerate conditions of negative contact: First, exclusive metarepresentations, second, constructing alternative representations as 'straw men' and evoke negative affects, third, a disagreeable style of communication and lack of respect, fourth, focusing on polemical/controversial social objects and thereby devaluing any interobjectivity. For example, the rhetorical devices of right wing populists aim at undermining trust between groups and break liberal consensus. They deny politeness by using a low style rhetorics. They construct malevo- 
lent meta-representations as antithetical construction of the enemy, they generate mirror-projections, positioning oneself as a moral victim, presenting minorities as aggressive and as powerful adversaries (Kasekamp et al., 2019).

\section{Discussion and outlook}

In the foregoing sections we presented an extension of social representation theory that appears to be necessary if we apply Moscovici's approach to intergroup situations. Moscovici himself was not very outspoken about intergroup behaviours and to my knowledge did not extensively consider the dynamics of social representations in the context of group interactions. One such example is his research on active or victim-centred minorities and majority relations (Moscovici et al., 1994; Moscovici, Pérez, 2007), which in our opinion must be viewed as the kernel for any intergroup approach in the sense elaborated in our section on 'it takes two to tango'. We are convinced that applying social representation theory to reflexive groups makes an intergroup perspective unavoidable and, if we envisage encounters and interactions between members of different cultural groups, there must be a process that allows each individual to develop and build upon an understanding of the other for successful communication and cooperation. This process is the formation of meta-representations.

Now, given that meta-representations are crude images of another person's socio-cultural constitution, their expected behaviour tendencies, and relevant characteristics, is a meta-representation not simply a stereotype? The so-called stereotype content model (Fiske et al., 2002) postulates two dimensions, functional competence (competent - incompetent) and interpersonal warmth (warm - cold). On an abstract level these dimensions may capture the majority of intergroup stereotyping that can be expected, but it would not be sufficient for basing one's real interactive behaviour with an opponent on it. Equally, stereotypes are frequently considered largely wrong and prejudiced with regard to the target group (e.g. Yzerbyt, 2016). In fact, a largely biased outgroup image constructed primarily according to ingroup interests is not a useful guide for establishing a productive intergroup relationship. This role is taken by meta-representations where the interactants maintain an interest in concerted interaction, communication, cooperation and where, of course, the opposite and conflictual positions are also possible.

A metarepresentation may be built upon culturally shared fixed stereotypes about an outgroup and constantly elaborated according to new intergroup experiences including conflicts and agreeableness. Metarepresentations are flexible, they contain resources both for confrontation and for reconciliation and they can be intentionally manipulated by the authorities. Intentional formation of metarepresentational knowledge occurs in social and transcultural competence training necessary for individual pre-adaptation in a non-familiar context, and, for example, also in the professional training of secret service agents or executives in transnational companies. Knowledge about the outgroup in different communicative situations, skills of perspective taking, motivation to establish and maintain contact with members of other groups; these are elements of metarepresentations that can be deliberately acquired. It should be clear that the workings of metarepresentations are intimately linked to the concept of interobjectivity as well as to 
the communication processes required for bridging the gap between the objective worlds of two groups. Then there are the ethical pitfalls in meeting members of other ethnic and religious groups that can easily amount to blocking cooperation when each other's identity would be threatened by openly accepting the opposite person's values.

Coming back to the examples presented in the beginning of the article: discursive non-understanding of a question about reincarnation may be overcome by a response: What do you mean? Please explain. On a superficial level of nonunderstanding on the part of the recipient there is a gap in the cultural knowledge about a particular belief system of the partner. Perhaps there are representational barriers that prevent them to ask clarification in the particular communicative situation? On a deeper level of non-understanding, the partners may be not able to define the communicative situation; was it a joke? An insult? A rhetorical question? Should I understand the question literally or allegorically? What was the context of the encounter, i.e. a joint activity, an inter-personal situation, on the basis of which a shared reality could be built?

The second initial example concerns misunderstanding the feelings of a person who relies on a non-familiar matrix of affective meanings. It demonstrates the necessity of intercultural empathy and affective component in metarepresentations for smooth interaction. These are potentially constructive events (Wagner, 1996. P. 110) that reveal gaps or failures in metarepresentations. Given the wide field of intergroup relationships we are convinced that besides our present approach there are still other conceptual developments possible and necessary in the context of Social Representation Theory.

\section{References}

Ben-Asher, S., Wagner, W., \& Orr, E. (2006). Thinking groups: Rhetorical enactment of collective identity in three Israeli Kibbutzim. Asian Journal of Social Psychology, 9(2), 112-122.

Berry, M., Carbaugh, D., Innreiter-Moser, C., Nurmikari-Berry, M., \& Oetsch, W. (2010). "That's not me". Learning to cope with sensitive cultural issues. Brussels, BE: University College Francisco Ferrer and Vesalius College.

Bilali, R. (2014). Between fiction and reality in post-genocide Rwanda: Reflections on a social-psychological media intervention for social change. Journal of Social and Political Psychology, 2(1), 387-400.

Bilali, R., \& Staub, E. (2017). Interventions in real-world settings: Using media to overcome prejudice and promote intergroup reconciliation in Central Africa. In C. Sibley \& K. Barlow (Eds.), Cambridge Handbook of the Psychology of Prejudice (pp. 607-631). Cambridge, UK: Cambridge University Press. https://doi.org/10.1017/9781316161579.027

Breakwell, G.M. (2015). Identity process theory. In G. Sammut, E. Andreouli, G. Gaskell, \& J. Valsiner (Eds.), The Cambridge Handbook of Social Representations (pp. 250-267). Cambridge, UK: Cambridge University Press.

Clark, H.H., \& Brennan, S.E. (1991). Grounding in communication. In L.B. Resnick, J.M. Levine, \& J.S.D. Teasley (Eds.), Perspectives on Socially Shared Cognition (pp. 127-149). American Psychological Association.

Cornelissen, J.J., \& Van Wyk, A.S. (2008). Professional socialisation: An influence on professional development and role definition. South African Journal of Higher Education, 21(7), 826-841. https://doi.org/10.4314/sajhe.v21i7.25745

Elcheroth, G., \& Reicher, S. (2017). Identity, violence and power: Mobilizing hatred, demobilising dissent. London, UK: Palgrave Macmillan. 
Fiske, S.T., Cuddy, A.J.C., Glick, P., \& Xu, J. (2002). A model of (often mixed) stereotype content: Competence and warmth follow from perceived status and competition. Journal of Personality and Social Psychology, 82(6), 678-902.

Gagnon, V.P. (2004). The myth of ethnic war: Serbia and Croatia in the 1990s. Ithaca, NY: Cornell University Press.

Gillespie, A. (2008). Social representations, alternative representations and semantic barriers. Journal for the Theory of Social Behaviour, 38(4), 375-391. http://dx.doi.org/10.1111/j.14685914.2008.00376.x

Global Slavery Index. (2018). Country Data. Retrieved April 24, 2020, from https://www.globalslaveryindex.org/2018/data/country-data/saudi-arabia/

Harré, R., \& Sammut, G. (2013). What lies between? In G. Sammut, P. Daanen \& F.M. Moghaddam (Eds.), Understanding the Self and Others: Explorations in Intersubjectivity and Interobjectivity (pp. 15-30). London, UK: Routledge.

Jovchelovitch, S. (2001). Social representations, public life, and social construction. In K. Deaux \& G. Philogene (Eds.), Representations of the Social: Bridging Theoretical Traditions. Oxford: Blackwell. (Reprinted from: SocReps).

Jovchelovitch, S. (2019). Knowledge in context: Representations, community and culture. London, UK: Routledge.

Kasekamp, A., Madisson, M.L., \& Wierenga, L. (2019). Discursive opportunities for the Estonian populist radical right in a digital society. Problems of Post-Communism, 66(1), $47-58$.

Krys, K., Vauclair, M., Lun, V.M.-C., Bond, M.H., Capaldi, C.A., Domínguez-Espinosa, A., Torres, C., Manickam, L.S.S., Lipp, O.V., Xing, C., Antalíková, R., Pavlopoulos, V., Teyssier, J., Hur, T., Hansen, K., Szarota, P., Ramadan, A.A., Burtceva, E., Chkhaidze, A., . . Y Yu, A.A. (2016). Be careful where you smile: Culture shapes judgments of intelligence and honesty of smiling individuals. Journal of Non-Verbal Behaviour, 40(2), 101-116. https://doi.org/10.1007/s10919-015-0226-4

Levine, J.M., \& Moreland, R.L. (1991). Culture and socialization in work groups. In L.B. Resnick, J.M. Levine \& S.D. Teasley (Eds.), Perspectives on Socially Shared Cognition. Washington, DC: American Psychological Association.

Marková, I. (2016). The dialogical mind. Cambridge: Cambridge University Press.

MENA Research and Studies Center. (2021). The Danger of Islamist attitudes towards German and Austrian Students. Retrieved January 14, 2021, from https://mena-studies.org/thedanger-of-islamist-attitudes-towards-german-and-austrian-students/

Moghaddam, F.M. (2003). Interobjectivity and Culture. Culture \& Psychology, 9(3), 221-232. https://doi.org/10.1177/1354067X030093004

Moliner, P., \& Bovina, I. (2020). On Serge Moscovici's 95th anniversary: The theory of social representations - history, postulates and dissemination. RUDN Journal of Psychology and Pedagogics, 17(3), 542-553. https://doi.org/10.22363/2313-1683-2020-17-3-542-553

Moscovici, S. (1988). Notes toward a description of social representations. European Journal of Social Psychology, 18(3), 211-250.

Moscovici, S. (2000). Social representations - explorations in social psychology (G. Duveen, Trans.). Cambridge: Polity Press.

Moscovici, S., Mucchi-Faina, A., \& Maass, A. (Eds.). (1994). Minority influence. Chicago, IL: Nelson-Hall Publishers.

Moscovici, S., \& Pérez, J.A. (2007). A study of minorities as victims. European Journal of Social Psychology, 37(4), 725-746.

Padilla Cruz, M. (2010). Metarepresentation and indirect complaints: A relevance-theoretic approach. In E. Wałaszewska, M. Kisielewska-Krysiuk, \& A. Piskorska (Eds.), In the Mind and Across Minds: A Relevance-Theoretic Perspective on Communication and Translation (pp. 1-11). Newcastle-upon-Tyne, UK: Cambridge Scholars Publishing.

Page, G. (2005). Professional socialisation of valuers: What the literature and professional bodies offers. International Education Journal, 5(5), 105-116. 
Paluck, E.L. (2009). Reducing intergroup prejudice and conflict using the media: A field experiment in Rwanda. Journal of Personality and Social Psychology, 96(3), 574-5587. https://doi.org/10.1037/a0011989

Paluck, E.L., \& Green, D.P. (2009a). Deference, dissent, and dispute resolution: An experimental intervention using mass media to change norms and behavior in Rwanda. American Political Science Review, 103(4), 622-644.

Paluck, E.L., \& Green, D.P. (2009b). Prejudice reduction: What works? A review and assessment of research and practice. Annual Review of Psychology, 60, 339-367.

Putra, I.E., \& Wagner, W. (2017). Prejudice in inter-religious context: The role of metaprejudice and majority-minority status. Journal of Community \& Applied Social Psychology, 27(3), 226-239. https://doi.org/10.1002/casp.2305

Raudsepp, M. (2005). Why is it so difficult to understand the Theory of Social Representations? Culture and Psychology, 11(4), 455-468.

Raudsepp, M., \& Wagner, W. (2012). The essentially Other--representational processes that divide groups. In I. Marková \& A. Gillespie (Eds.), Trust and Conflict: Representation, Culture and Dialogue (pp. 105-122). London: Routledge. (Reprinted from: SocReps).

Sen, R., \& Wagner, W. (2005). History, emotions and hetero-referential representations in inter-group conflict: The example of Hindu-Muslim relations in India. Papers on Social Representations, 14, 2.1-2.23. Retrieved January 14, 2021, from http://www.psych.lse.ac.uk/psr/

Sen, R., \& Wagner, W. (2009). Cultural mechanics of fundamentalism: Religion as ideology, divided identities and violence in post-Gandhi India. Culture \& Psychology, 15(3), 299-326.

Tajfel, H. (1978). Differentiation between social groups: studies in the social psychology of intergroup relations. London: Academic Press.

Turner, J.C., \& Reynolds, K. (2012). Self-categorization theory. In P.A.M. Paul, A.M. Van Lange, A.W. Kruglanski \& E.T. Higgins (Eds.), Handbook of Theories in Social Psychology (pp. 399-417). London, UK: Sage. https://doi.org/http://dx.doi.org/10.4135/9781446249222.n46

Wagner, W. (1995). Social representations, group affiliation, and projection: Knowing the limits of validity. European Journal of Social Psychology, 25, 125-140.

Wagner, W. (1996). Queries about social representation and construction. Journal for the Theory of Social Behaviour, 26, 95-120.

Wagner, W. (2015). Representation in action. In G. Sammut, E. Andreouli, G. Gaskell \& J. Valsiner (Eds.), The Cambridge Handbook of Social Representations (pp. 12-28). Cambridge, UK: Cambridge University Press.

Wagner, W. (2021). Groups in contact: Meta-representations, interobjectivity, and cultural incompatibilities. Journal for the Theory of Social Behaviour, 51(1), 2-24. https://doi.org/10.1111/jtsb.12259

Wagner, W., \& Hayes, N. (2005). Everyday discourse and common sense - the theory of social representations. Basingstoke: Palgrave-Macmillan.

Wagner, W., Kello, K., \& Rämmer, A. (2018). Making social objects: The theory of social representation. In A. Rosa \& J. Valsiner (Eds.), The Cambridge Handbook of Sociocultural Psychology (2nd edition) (pp. 130-147). Cambridge, UK: Cambridge University Press. https://doi.org/10.1017/9781316662229

Wagner, W., Kronberger, N., \& Seifert, F. (2002). Collective symbolic coping with new technology: Knowledge, images and public discourse. British Journal of Social Psychology, 41(3), 323-343. https://doi.org/10.1348/014466602760344241

Yzerbyt, V. (2016). Intergroup stereotyping. Current Opinion in Psychology, 11, 90-95. https://doi.org/10.1016/j.copsyc.2016.06.009

\section{Article history:}

Received: 5 March 2021

Revised: 18 April 2021

Accepted: 15 May 2021 


\title{
For citation:
}

Wagner, W., \& Raudsepp, M. (2021). Representations in intergroup relations: Reflexivity, meta-representations, and interobjectivity. RUDN Journal of Psychology and Pedagogics, 18(2), 332-345. http://dx.doi.org/10.22363/2313-1683-2021-18-2-332-345

\section{Bio notes:}

Wolfgang Wagner, Ph.D., currently is professor of social psychology at the University of Tartu (Tartu, Estonia), after having retired from Johannes Kepler University of Linz, Austria. $\mathrm{He}$ received his $\mathrm{PhD}$ at the University of Vienna, Austria. He held visiting positions at several foreign universities, including Cambridge (UK), Maison des Sciences de l'Homme (Paris), and Kyoto University (Japan). His interests are in theoretical and empirical work on societal psychology, social and cultural knowledge, popularisation of science, intergroup relationship, Social Representation Theory and political discourse. He authored and edited several books on Social Representations Theory. For example, "Everyday Discourse and Common Sense - The Theory of Social Representations" (co-edited with N. Hayes) is a standard on the Theory of Social Representations. His latest contribution is in Oxford Research Encyclopedia of Psychology on the history of Social Representation Theory (2020). He is associate editor and board member of several scholarly journals, including "Papers on Social Representations". E-mail: wolfgang.wagner@ut.ee

Maaris Raudsepp, Ph.D., is Senior Research Fellow at the Institute for International and Social Studies in the School of Governance, Law and Society of Tallinn University (Tallinn, Estonia). She has an MSc degree in social psychology and PhD in sociology. Her research interests include value change and intergroup relations in the frameworks of the theory of social representations, semiotics and sociocultural psychology. She has publications on the promotion of intergroup trust, processes of acculturation, regulative role of values, forms of group identity, ethnic self-esteem, social representations of human rights and equal treatment, as well as on autobiographical memory and personal meaning construction. E-mail: maaris.raudsepp@tlu.ee

\section{Представления в межгрупповых отношениях: рефлексивность, метапредставления и интеробъективность}

\author{
В. Вагнер ${ }^{1 \bowtie}$, М. Раудсепп ${ }^{2}$ \\ ${ }^{1}$ Тартуский университет, \\ Эстонская Республика, 50409, Tapmy, Näituse, д. 2 \\ ${ }^{2}$ Таллиннский университет \\ Эстонская Республика, 10120, Таллинн, Uus-Sadama, д. 5 \\ $\checkmark$ wolfgang.wagner@ut.ee
}

\begin{abstract}
Аннотация. Социальные и культурные группы характеризуются общими системами социальных объектов и проблем, которые составляют их объективную реальность и идентичность их членов. Межличностное взаимодействие внутри таких групп требует системы всеобъемлющих представлений, обеспечивающих согласованное взаимодействие между индивидами. Для того чтобы уменьшить возможные разногласия при взаимодействии, всеобъемлющие представления включают в себя фрагменты репрезентативной структуры взаимодействующего, а также его потенциальные ценности и пове-
\end{abstract}


дение. В более широком масштабе то же самое относится к общению и взаимодействию между членами различных культурных групп, где взаимодействующие должны располагать приблизительным знанием соответствующих характеристик другой культуры. Это взаимное знание называется метапредставлениями, которые дополняют собственные ценности и способы мышления субъектов. Концепция метапредставлений дополняет теорию социальных представлений применительно к межкультурному и межэтническому взаимодействию.

Ключевые слова: теория социальных представлений, межгрупповое поведение, сотрудничество, метапредставление, интеробъективность, всеобъемлющие представления

\section{История статьи:}

Поступила в редакцию: 5 марта 2021 г.

Принята к печати: 15 мая 2021 г.

\section{Для цитирования:}

Wagner $W$., Raudsepp M. Representations in intergroup relations: reflexivity, metarepresentations, and interobjectivity // Вестник Российского университета дружбы народов. Серия: Психология и педагогика. 2021. Т. 18. № 2. С. 332-345. http://dx.doi.org/10.22363/2313-1683-2021-18-2-332-345

\section{Сведения об авторах:}

Вагнер Вольфганг, Ph.D., в настоящее время является профессором социальной психологии в Институте психологии Таллиннского университета (Таллинн, Эстония). Получил докторскую степень по психологии в Венском университете (Вена, Австрия), долгие годы работал в Университете Иоганнеса Кеплера (Линц, Австрия), неоднократно был приглашенным профессором в зарубежных университетах, например, в Кембриджском университете (Великобритания), Доме наук о человеке (Париж, Франция), Университете Киото (Япония). Его научные интересы связаны с теоретическими и эмпирическими исследованиями в области социетальной психологии, социального и культурного познания, популяризации науки, межгрупповых отношений, теории социальных представлений, политического дискурса. Автор, peдактор и соредактор нескольких монографий по проблематике теории социальных представлений. Например, монография Everyday Discourse and Common Sense The Theory of Social Representations под общей редакцией В. Вагнера и Н. Хэйса, опубликованная в 2005 г., - общепризнанный стандарт научных публикаций по проблеме социальных представлений, а самой современной публикацией В. Вагнера по данной проблеме является статья по истории теории социальных представлений в Оксфордской исследовательской энциклопедии 2020 г. Доктор В. Вагнер ассоциированный редактор и член редколлегии нескольких научных журналов, включая Papers on Social Representations. E-mail: wolfgang.wagner@ut.ee

Paydcenn Maapuc, Ph.D., старший научный сотрудник Института международных и социальных исследований факультета управления, права и общества Таллиннского университета (Таллинн, Эстония). Защитила магистерскую диссертацию по социальной психологии и докторскую диссертацию по социологии. Ее исследовательские интересы включают проблемы изменения ценностей и межгрупповые отношения в рамках теории социальных представлений, семиотику и социокультурную психологию. Имеет научные публикации по вопросам продвижения межгруппового доверия, процессам аккультурации, регулирующей роли ценностей, форм групповой идентичности, этнической самооценки, социальных представлений о правах человека и равенства, а также автобиографической памяти и конструированию личностного смысла. E-mail: maaris.raudsepp@tlu.ee 